\title{
Management of Dilutional Coagulopathy during Pediatric Major Surgery
}

\author{
Thorsten Haas $^{\mathrm{a}} \quad$ Jacqueline Mauch $^{\mathrm{a}}$ Markus Weiss ${ }^{\mathrm{a}} \quad$ Markus Schmugge $^{\mathrm{b}}$ \\ ${ }^{a}$ Department of Anaesthesia, \\ ${ }^{\mathrm{b}}$ Department of Haematology, University Children's Hospital Zurich, Switzerland
}

\section{Keywords}

Blood loss · Blood products · Blood transfusion .

Colloids $\cdot$ Hemodilution $\cdot$ Hemostatic disorder .

Perioperative · Pediatric anesthesia

\section{Summary}

Perioperative dilutional coagulopathy is a major coagulation disorder during adult and pediatric surgery. Although the main underlying mechanisms are comparable, data of the development and management of dilutional coagulopathy in children are scarce. Observational data showed that intraoperative coagulation disorders mainly based on complex disturbances of clot firmness including acquired fibrinogen as well as factor XIII deficiencies, while clotting time and platelet counts remained fairly stable. A fast and reliable monitoring of the entire coagulation process (e.g. thrombelastometry) might be of extreme value for detection and guidance of effective coagulation management. Although the transfusion of fresh frozen plasma was recommended in several guidelines, the use of coagulation factors might offer an alternative and potentially superior approach in managing perioperative coagulation disorders. Further studies are urgently needed to determine the efficacy of modern coagulation management.

\author{
Schlüsselwörter \\ Blutverlust · Blutprodukte · Bluttransfusion . \\ Kolloide · Hämodilution · Hämostatische Störung · \\ Perioperativ · Pädiatrische Anästhesie
}

\section{Zusammenfassung}

Das Auftreten einer Dilutionskoagulopathie im pädiatrischen operativen Bereich ist ein klinisches relevantes Problem. Eine schnelle und zuverlässige Laboranalyse ist für die Diagnosesicherung und Steuerung der Therapie von besonderer Bedeutung. Viskoelastische Methoden wie das ROTEM ${ }^{\circledR}$ oder TEG ${ }^{\circledR}$ scheinen hierfür besonders geeignet zu sein. Der erworbene Fibrinogen-Mangel ist regelmässig bei Auftreten einer Dilutionskoagulopathie zu diagnostizieren und kann optimalerweise mittels Fibrinogenkonzentrat therapiert werden, wobei nicht endgültig geklärt ist welcher perioperative Grenzwert für den Fibrinogen-Spiegel angestrebt werden sollte. Die Substitution anderer Gerinnungsfaktoren (z.B. FaktorXIII-Spiegel $<60 \%$ ) sollten ebenfalls auf laborchemischen Analysen basieren. Die Transfusion von gefrorenem Frischplasma (FFP) erfolgt in einer Dosis von $30 \mathrm{ml} /$ $\mathrm{kg}$ im Rahmen einer Massivblutung, sollte jedoch erst erwogen werden, wenn andere gerinnungsbeeinflussende Faktoren optimiert wurden (z.B. Fibrinogen-Mangel, Hyperfibrinolyse, Azidose, Hypothermie, Thrombozytopenie oder Thrombozytopathie). Basierend auf aktuellen Empfehlungen kann der routinemäßige Einsatz von rekombinantem Faktor VIla nicht empfohlen werden. Im Gegensatz dazu hat die Anwendung von Antifibrinolytika signifikant zur Reduktion des intraoperativen Blutverlusts und des Bedarfs an Bluttransfusionen bei nichtherzchirurgischen pädiatrischen Eingriffen beigetragen. Weitere kontrollierte Studien zur Evaluierung effektiver und sicherer laborbasierter Strategien zur Therapie der Dilutionskoagulopathie sind notwendig.

\section{KARGER \\ Fax +497614520714 \\ Information@Karger.de}

www.karger.com (c) 2012 S. Karger GmbH, Freiburg

$1660-3796 / 12 / 0392-0114 \$ 38.00 / 0$

Accessible online at:

www.karger.com/tmh
PD Dr. Thorsten Haas

Department of Anaesthesia

University Children's Hospital Zurich

Steinwiesstrasse 75, 8032 Zürich, Switzerland

Tel. +41 44 2668-152, Fax -032

thorsten.haas@kispi.uzh.ch 


\section{Introduction}

The causes of dilutional coagulopathy are complex, and both pro- and anticoagulant pathways are affected; but the underlying mechanisms are not fully understood. In terms of laboratory changes, it seems to be comparable to hemostatic changes during major hemorrhage following trauma injury [1].

Occurrence of generalized microvascular oozing in patients requiring massive transfusion was first described by Counts and colleagues in 1974 [2]. They found platelet count and fibrinogen level to be most useful laboratory tests for predicting abnormal bleeding and guiding therapy. The prothrombin time (PT) and partial thromboplastin time (PTT) were shown to correlate with generalized bleeding only if they were markedly prolonged. This observation was supported by retrospective analysis of 172 surgical patients undergoing massive transfusion that was published 3 years later [3]. However, in that study administration of platelet concentrates and/or fresh frozen plasma (FFP) without evaluation of hemostasis failed to decrease the requirements of whole blood and/or packed red cells. The authors concluded that a directed intervention after identification of the underlying disorder is likely to be more effective. In 1987, Ciavarella and colleagues [4] recommended initial treatment by transfusion of platelet concentrates in massive transfusion setting. That study group recommended supplemental FFP or cryoprecipitate if the fibrinogen level is less than $0.8 \mathrm{~g} / 1$. After major change in the treatment of massive blood loss in the 1990s towards pure component therapy and the use of plasma-poor packed red cells instead of whole blood, Hiippala and co-workers [5] were able to demonstrate for the first time that deficiency of fibrinogen develops earlier than any other hemostatic abnormality when plasma-poor red cells are used for the replacement of major blood loss in surgical patients. This observation was supported by more recent investigations focusing on the importance of acquired fibrinogen deficiency that seems to be the leading determinant in dilutional coagulopathy [6-10]. In addition, more recent data points toward the importance of factor XIII (FXIII) in clot stabilization during major surgery and consecutive blood loss [11].

Today, dilutional coagulopathy is usually defined as loss, consumption, or dilution of coagulation factors and occurs when blood is replaced with fluids that do not contain adequate coagulation factors [12]. Depending on the amount and the type of fluid replacement, dilution of cellular components and coagulation factors were inevitable. Based on the dynamic of blood loss and consequently loss and consumption of factors a clinical relevant dilution coagulopathy occurs constantly [13]. Moreover, disturbance of hemostatic potential might be further deteriorated by hypothermia, acidosis, and fibrinolysis, thus leading to worsening of patient's outcome [14]. If a critical threshold of plasma concentration of coagulation factors was reached, bleeding will be further perpetuated. The incidence of dilution coagulopathy was decreased by preparation of modern (nearly plasma-free) autologous blood products. In contrast to congenital bleeding disorders based on single coagulation factor deficiency, dilutional coagulopathy is related to multifactorial changes that affects thrombin generation, clot firmness, and fibrinolysis [15]. Therefore, it seems hard to predict if the complex interaction of cellular components, pro- and anticoagulant factors, and fibrinolytic activators and inhibitors will finally form a stable clot during moderate to severe hemodilution.

\section{Diagnosis of Dilutional Coagulopathy}

Unfortunately, routine plasmatic coagulation tests are of limited help for timely management of perioperative bleeding due to long turnaround times, insufficient differential diagnosis of complex acquired intraoperative coagulopathy, and insensitivity for function of fibrinogen, hyperfibrinolysis and platelet dysfunction [16]. Another meaningful limitation is that measurement of fibrinogen levels using the photometric Clauss assay can be considerably altered after massive fluid resuscitation and that colloids may induce erroneously increased levels of fibrinogen $[16,17]$.

Rotation thrombelastometry (ROTEM ${ }^{\circledR}$, AxonLab, Baden, Switzerland) offers an alternative approach to assess perioperative coagulation disorders by means of viscoelastic testing [18]. First results are available only 10 min after starting with testing and clot formation can be online observed by a bedside monitor. Data on the effective use of the ROTEM were published from adult liver transplantation [19], adult trauma patients [20], and intraoperative coagulation management in children [21, 22]. Notably, a normal ROTEM trace showed high negative predictive value and was suggested to early identify surgical bleeding by distinguishing it from coagulopathic bleeding [23]. Additionally, both devices were stated as golden standard for detecting hyperfibrinolysis, which may have deleterious impact on mortality. However, there is a lack of data proving the usefulness of a ROTEM-guided coagulation management in children and clinically meaningful trigger levels for initiating coagulation therapy.

Clinical observations have shown that intraoperative changes in hemostasis showed early signs of moderate to severe acquired hypofibrinogenemia as well as marked decrease in FXIII levels, while platelet count remained fairly stable [24]. In a retrospective analysis of 150 children with craniofacial surgery 33 experienced severe hypofibrinogenemia with levels $\leq 100 \mathrm{mg} / \mathrm{dl}$, while only 2 children showed platelet count $\leq 50,000 / \mu 1$ [25]. Throughout the surgical procedures children typically met the traditional laboratory criteria for dilutional coagulopathy (PT and activated partial thromboplastin time (aPTT) prolonged more than 1.5 times) while recent data showed no relevant changes as displayed in the ROTEM coagulation time (CT) [26]. Similar findings of other investigator groups [27-29] supported the modest correlation between 
ROTEM CT and PT or aPTT. Therefore, results of the clotting time in the ROTEM and results of PT or aPTT cannot be interchangeably used for detecting intraoperative hemostatic disorders. Based on results of the ROTEM, it may be concluded that currently recommended thresholds for PT/aPTT might overestimate the need for coagulation therapy, or, in other words, coagulation measurement of the entire process of clot formation started with thrombin generation (PT/aPTT) with close interaction to clot strength (fibrinogen) and final lysis. In contrast, ROTEM FibTEM A10 and MCF showed very high correlation to plasma fibrinogen levels. In addition, recently published data support the fact that the mechanical detection principle of fibrinogen testing seems to be more reliable than photometric techniques [17]. However, there are some important limitations that need to be considered when interpreting ROTEM results: inability to detect von Willebrand syndrome, platelet function disorders, or drug monitoring (e.g. vitamin $\mathrm{K}$ anatagonists) [16].

There was a clear advantage for ROTEM as compared to standard coagulation test concerning extensively shorter turnaround times, which will have impact on a timely and more targeted coagulation therapy [30-32].

\section{Influence of Colloids on the Development of Dilutional Coagulopathy}

Another important aspect of developing dilutional coagulopathy is the use of colloids and the combined interaction with hemostasis. There is fair evidence that colloids, especially high molecular solutions and dextrans, were linked to severe disturbance of clot formation [6, 33, 34]. By manufacturing new low molecular starches, impact on clot formation was significantly reduced, but depending on the amount of fluid given a marked impairment of hemostasis can be observed [35]. The negative impact can be specified as fibrin polymerization interaction with a consecutive distinct weakening of the clot. Additionally, specific interaction with von Willebrand factor (VWF) / FVIII and platelets were observed (e.g. von Willebrand-like syndrome) [33]. Even a colloid-mediated increase in fibrinolytic tendency by $\alpha_{2}$-antiplasmin-plasmin interaction was observed that may alter clot firmness [36-37].

As in adults, the use of colloids showed similar changes of the hemostatic profile in the pediatric population. The influence of colloids on hemostasis was investigated in a prospective trial in small children (3-15 kg body weight) who randomly received a bolus of $15 \mathrm{ml} / \mathrm{kg}$ of either albumin 5\%, 4\% modified gelatin solution or $6 \%$ hydroxyethyl starch (HES 130/0.4) after induction of anesthesia [38]. Fibrin polymerization as measured with the ROTEM FibTEM test was significantly decreased in all groups, but most pronounced in the HES group. In contrast, no relevant changes in the coagulation time that represents the phase of thrombin generation were observed. Notably, mean FXIII concentrations of $<60 \%$ were obtained in all groups after volume administration. A multicenter trial in 81 children aged $<2$ years who underwent noncardiac surgery showed no significant differences in hemodynamics, coagulation parameters, or blood loss if comparable amounts of $6 \%$ HES $(130 / 0.4)$ or albumin $5 \%$ were used for perioperative fluid resuscitation [39]. However, to date no conclusive statement can be made which type of fluid should be used to stabilize hemodynamics in children but having no relevant effect on hemostasis.

\section{Management of Dilutional Coagulopathy in Children}

It should be recognized that several publications investigated coagulopathies in the clinical setting of cardiac surgery. However, if cardiac bypass was used, additional disturbance of the coagulation system, such as platelet dysfunction, excessive fibrinolysis and consumption of coagulation factors, might aggravate dilution following administration of the priming volume [40]. Thus, coagulation testing and management should be adapted to the type of surgery.

A modern concept of bleeding therapy should be adapted to local conditions and could consist of a bedside coagulation testing (e.g. ROTEM), targeted administration of purified coagulation factors leading to fast responsiveness, and calculable increase in those factors that were critically decreased [16]. It needs to be mentioned that reference ranges for ROTEM parameters in children are age-dependent and were evaluated recently [27]. The most striking finding in that study was that children aged $0-3$ months exhibited accelerated coagulation and strong clot firmness, despite showing prolonged standard plasma coagulation test results. Similar to adults, also in children fibrinogen concentrations, platelet count and FXIII contribute to clot firmness as measured with ROTEM assays. In addition, it was demonstrated that children aged 4-24 months showed the lowest $2.5 \%$ percentiles for clot strength, indicating low reserve when exposed to hemodilution and blood loss.

Administration of fresh frozen plasma was recommended for treatment of dilution coagulopathy and in massive transfusion scenarios [41-46]. Remarkably, there is not a single randomized controlled trial published proving the beneficial use of FFP for treatment of perioperative bleeding in children with respect to improved clinical outcome. One of the rarely published randomized controlled trials using prophylactic FFP administration in preterm babies to prevent or reduce periventricular hemorrhage failed to provide evidence for routine early use of FFP [47]. Observations of a pilot study in 30 children revealed that the use of FFP for intraoperative volume replacement had led to significantly higher fibrinogen levels $(184.4 \pm 9.2 \mathrm{mg} / \mathrm{dl})$ as compared to colloid fluid resuscitation using albumin $(106.4 \pm 7.6 \mathrm{mg} / \mathrm{dl})$ [48]. However, there was no difference in terms of mean amounts of intraoperative or postoperative blood loss and transfusion requirements. 
A meta-analysis by Stanworth et al. [47] revealed no significant improvement if FFP was used for treatment of coagulopathic bleeding. The British guideline stated a grade A recommendation to avoid the use of FFP as a simple volume replacement [49]. Recommended dosages of 10-15 ml/kg FFP may not be adequate to achieve a clinically meaningful improvement in hemostatic potential [50-52], but higher doses were often be limited by the considerable necessary volume load.

Fibrinogen was specified to be the first clotting factor to fall to critically low levels during life-threatening hemorrhage in adults and children. Intraoperative substitution with human fibrinogen concentrate was effectively used to treat fibrinogen deficiency in a case report series in pediatric craniofacial surgery [21], by a prospective randomized trial in adult patients undergoing aortic valve/ascending aorta replacement [53], during adult radical cystectomy [54], in a clinical trial on adult major orthopedic surgery [35], and in a case report series in patients with massive hemorrhage [5557]. Fibrinogen concentrate offers a very good safety profile $[58,59]$, but clinical evidence for recommendation of minimal tolerable fibrinogen levels by good-quality trials is still lacking. Recent European guidelines [45, 46] recommend higher fibrinogen cut-off levels (150-200 mg/dl) as compared to international guidelines [60].

There is growing evidence that acquired FXIII deficiency is frequent in the surgical and acute care setting [61]. A study of neurosurgical patients showed that postoperative fibrinogen levels of $150 \mathrm{mg} / \mathrm{dl}$ together with a marginal decrease of FXIII $(<60 \%)$ was associated with a 12 -fold increase in relevant bleeding (need for transfusion and/or surgical revision) [62]. Results from a prospective randomized trial in adults [63] and other clinical investigations $[62,64,65]$ underline the potential need for maintaining adequate FXIII levels (above 50-60\%) during perioperative bleeding situations, but need further investigations.

Data from off-label treatment of recombinant activated factor VII (rFVIIa) was published from neurosurgical procedures in children [66, 67]. Results from a prospective randomized trial in pediatric cardiac surgery did not show significant differences in blood loss after administration of $40 \mu \mathrm{g} / \mathrm{kg}$ rFVIIa as compared to placebo [68]. Likewise, two prospective randomized trials from blunt or penetrating injuries in adults failed to reduce transfusion of RBCs after administration of rFVIIa as compared to placebo [69]. Thus, administration of rFVIIa for treatment of severe bleeding may only be efficacious if critical amounts of fibrinogen and platelets were established or if extremely high doses of rFVIIa were administered [70].

Antifibrinolytic agents have shown to significantly decrease blood loss and reduce allogeneic blood transfusion in pediatric cardiac and scoliosis surgery $[71,72]$. Similar beneficial effects of tranexamic acid were also observed in a doubleblind randomized trial in pediatric craniosynostosis surgery [73]. However, optimum doses are unknown, and reported dosing ranges from 10 to $100 \mathrm{mg} / \mathrm{kg}$ loading doses and $1-10$ $\mathrm{mg} / \mathrm{kg} / \mathrm{h}$ infusion rates.

\section{Conclusion}

Development of dilutional coagulopathy during major surgery is an important clinical problem. There is a pivotal need for fast and reliable coagulation testing that guides through (mostly multifactorially caused) coagulopathic bleeding. This might effectively be managed by using a viscoelastic point-of-care device (ROTEM or thrombelastography). Acquired fibrinogen deficiency is a common finding and should be treated with substitution of fibrinogen concentrate, whereby minimal plasma fibrinogen levels need to be defined by further well-controlled studies. Substitution with other coagulation factors (e.g. FXIII levels $<60 \%$ ) should be based on laboratory findings. FFP transfusion in a dose of 30 $\mathrm{ml} / \mathrm{kg}$ might be useful for treatment of severe hemorrhage as adjunctive to basic treatment with coagulation factors but should only be considered after exclusion of any other factor that might influence hemostasis (i.e. fibrinogen deficiency, hyperfibrinolysis, acidosis, hypothermia, low platelet count/ impaired platelet function). Based on current literature, routine use of rFVIIa was not supported. Perioperative treatment with antifibrinolytic agents might be helpful in reducing the amount of bleeding and reducing transfusion requirements in noncardiac pediatric surgery with a high risk of bleeding. Further well-controlled studies are urgently needed to determine the effect of a targeted, laboratorybased coagulation management for treatment of pediatric dilutional coagulopathy.

\section{Disclosure Statement}

Dr. Haas has received a speaker fee from CSL Behring and Octapharma AG.

\section{References}

1 Meißner A, Schlenk G: Massive bleeding and massive transfusion. Transfus Med Hemother 2012; 39(2):73-84.

$\checkmark 2$ Counts RB, Haisch C, Simon TL, Maxwell NG, Heimbach DM, Carrico CJ: Hemostasis in massively transfused trauma patients. Ann Surg 1979;190:91-99.
3 Mannucci PM, Federici AB, Sirchia G: Hemostasis testing during massive blood replacement. A study of 172 cases. Vox Sang 1982;42:113-123.
4 Ciavarella D, Reed RL, Counts RB, Baron L, Pavlin E, Heimbach DM, Carrico CJ: Clotting factor levels and the risk of diffuse microvascular bleeding in the massively transfused patient. $\mathrm{Br} \mathrm{J}$ Haematol 1987;67:365-368. 
5 Hiippala ST, Myllyla GJ, Vahtera EM: Hemostatic factors and replacement of major blood loss with plasma-poor red cell concentrates. Anesth Analg 1995;81:360-365.

6 Fenger-Eriksen C, Tonnesen E, Ingerslev J, Sorensen B: Mechanisms of hydroxyethyl starch-induced dilutional coagulopathy. J Thromb Haemost 2009; 7:1099-1105.

7 Levy JH: Massive transfusion coagulopathy. Semin Hematol 2006;43(1 suppl 1):S59-S63.

8 Fries D: Dilutionskoagulopathie. Entstehung, Diagnostik und Management. Haemostaseologie 2006; 26(suppl 1):S15-S19.

$\checkmark$ Kozek-Langenecker S: Management of massive operative blood loss. Minerva Anestesiol 2007;73: 401-415.

10 Innerhofer P, Kienast J: Principles of perioperative coagulopathy. Best Pract Res Clin Anaesthesio 2010;24:1-14.

11 Korte W: F. XIII in perioperative coagulation management. Pract Res Clin Anaesthesiol 2010;24:8593.

12 Ho AM, Karmakar MK, Dion PW: Are we giving enough coagulation factors during major trauma resuscitation? Am J Surg 2005;190:479-484.

13 Van der Linden PJ, Ickx BE: The effects of colloid solutions on hemostasis. Can J Anaesth 2006;53 (suppl):S30-S39.

14 Cosgriff N, Moore EE, Sauaia A, Kenny-Moynihan M, Burch JM, Galloway B: Predicting life-threatening coagulopathy in the massively transfused trauma patient: hypothermia and acidoses revisited. J Trauma 1997;42:857-861.

15 Bolliger D, Gorlinger K, Tanaka KA: Pathophysiology and treatment of coagulopathy in massive hemorrhage and hemodilution. Anesthesiology 2010;113:1205-1219.

16 Kozek-Langenecker SA: Perioperative coagulation monitoring. Best Pract Res Clin Anaesthesiol 2010; 24:27-40.

17 Fenger-Eriksen C, Moore GW, Rangarajan S, Ingerslev J, Sorensen B: Fibrinogen estimates are influenced by methods of measurement and hemodilution with colloid plasma expanders. Transfusion 2010;50:2571-2576.

18 Luddington RJ: Thrombelastography/thromboelastometry. Clin Lab Haematol 2005;27:81-90.

19 Wang SC, Shieh JF, Chang KY, Chu YC, Liu CS, Loong CC, Chan KH, Mandell S, Tsou MY: Thromboelastography-guided transfusion decreases intraoperative blood transfusion during orthotopic liver transplantation: randomized clinical trial. Transplant Proc 2010;42:2590-2593.

-20 Schochl H, Nienaber U, Hofer G, Voelckel W, Jambor C, Scharbert G, Kozek-Langenecker S, Solomon C: Goal-directed coagulation management of major trauma patients using thromboelastometry (ROTEM)-guided administration of fibrinogen concentrate and prothrombin complex concentrate. Crit Care 2010;14:R55.

-21 Haas T, Fries D, Velik-Salchner C, Oswald E, Innerhofer P: Fibrinogen in craniosynostosis surgery. Anesth.Analg 2008;106:725-731.

-22 Romlin BS, Wahlander H, Berggren H, Synnergren M, Baghaei F, Nilsson K, Jeppsson A: Intraoperative thromboelastometry is associated with reduced transfusion prevalence in pediatric cardiac surgery. Anesth Analg 2011;112:30-36.

23 Cammerer U, Dietrich W, Rampf T, Braun SL, Richter JA: The predictive value of modified computerized thromboelastography and platelet function analysis for postoperative blood loss in routine cardiac surgery. Anesth Analg 2003;96:51-57.
24 Haas T, Korte W, Spielmann N, Mauch J, Madjdpour C, Schmugge M, Weiss M: Perioperative course of FXIII in children undergoing major surgery. Paediatric Anaesthesia 2011; doi: 10.1111/ j.1460-9592.2011.03709.x.

25 Stricker PA, Fiadjoe JE, Davis AR, Sussman E, Burgess BJ, Ciampa B, Mendelsohn J, Bartlett SP, Sesok-Pizzini DA, Jobes DR: Reconstituted blood reduces blood donor exposures in children undergoing craniofacial reconstruction surgery. Paed Anaesth 2011;21:54-61.

26 Haas T, Spielmann N, Mauch J, Madjdpour C, Speer O, Schmugge M, Weiss M: Comparison of thrombelastometry $\left(\right.$ ROTEM $\left.^{\circledR}\right)$ with standard plasmatic coagulation testing in paediatric surgery. Br J Anaesth 2011;108:36-41.

27 Oswald E, Stalzer B, Heitz E, Weiss M, Schmugge M, Strasak A, Innerhofer P, Haas T: Thromboelastometry $\left(\right.$ ROTEM $\left.^{\circledR}\right)$ in children: age-related reference ranges and correlations with standard coagulation tests. Br J Anaesth 2010;105:827-835.

28 Rugeri L, Levrat A, David JS, Delecroix E, Floccard B, Gros A, Allaouchiche B, Negrier C: Diagnosis of early coagulation abnormalities in trauma patients by rotation thrombelastography. J Thromb Haemost 2007;5:289-295.

29 Coakley M, Reddy K, Mackie I, Mallett S: Transfusion triggers in orthotopic liver transplantation: a comparison of the thromboelastometry analyzer, the thromboelastogram, and conventional coagulation tests. J Cardiothorac Vasc Anesth 2006;20: 548-553.

30 Wegner J, Popovsky MA: Clinical utility of thromboelastography: one size does not fit all. Semin Thromb Hemost 2010;36:699-706.

31 Ganter MT, Hofer CK: Coagulation monitoring: current techniques and clinical use of viscoelastic point-of-care coagulation devices. Anesth Analg 2008;106:1366-1375.

32 Johansson PI, Stissing T, Bochsen L, Ostrowski SR: Thrombelastography and thromboelastometry in assessing coagulopathy in trauma. Scand $\mathrm{J}$ Trauma Resusc Emerg Med 2009;17:45.

33 Kozek-Langenecker S, Scharbert G: Comparing the effects of colloids on clot formation. Anaesthesia 2008;63:673-674; author reply 674.

34 de Jonge E, Levi M, Berends F, van der Ende AE, ten Cate JW, Stoutenbeek CP: Impaired haemostasis by intravenous administration of a gelatin-based plasma expander in human subjects. Thromb Haemost 1998;79:286-290.

35 Mittermayr M, Streif W, Haas T, Fries D, VelikSalchner C, Klingler A, Oswald E, Bach C, Schnapka-Koepf M, Innerhofer P: Hemostatic changes following crystalloid or colloid fluid administration during major orthopedic surgery: role of fibrinogen administration. Anesth Analg 2007; 105:905-917.

36 Mittermayr M, Streif W, Haas T, Fries D, VelikSalchner C, Klingler A, Innerhofer P: Effects of colloid and crystalloid solutions on endogenous activation of fibrinolysis and resistance of polymerized fibrin to recombinant tissue plasminogen activator added ex vivo. Br J Anaesth 2008;100:307314.

37 Nielsen VG: Hydroxyethyl starch enhances fibrinolysis in human plasma by diminishing alpha2antiplasmin-plasmin interactions. Blood Coagul Fibrinolysis 2007;18:647-656.

38 Haas T, Preinreich A, Oswald E, Pajk W, Kuehbacher G, Innerhofer P: Effects of albumin 5\% and artificial colloids on clot formation in small infants. Anaesthesia 2007;62:1000-1007.
39 Standl T, Lochbuehler H, Galli C, Reich A, Dietrich G, Hagemann H: HES 130/0.4 (Voluven) or human albumin in children younger than $2 \mathrm{yr}$ un dergoing non-cardiac surgery. A prospective, randomized, open label, multicentre trial. Eur J Anaesthesiol 2008;25:437-445.

40 Friesen RH, Perryman KM, Weigers KR, Mitchell MB, Friesen RM: A trial of fresh autologous whole blood to treat dilutional coagulopathy following cardiopulmonary bypass in infants. Paed Anaesth 2006;16:429-435.

41 Stainsby D, MacLennan S, Thomas D, Isaac J, Hamilton PJ: Guidelines on the management of massive blood loss. Br J Haematol 2006;135:634-641.

42 Lacroix J, Hebert PC, Hutchison JS, Hume HA, Tucci M, Ducruet T, Gauvin F, Collet JP, Toledano BJ, Robillard P, Joffe A, Biarent D, Meert K, Peters MJ: Transfusion strategies for patients in pediatric intensive care units. N Engl J Med 2007;356: 1609-1619.

43 Morley SL: Red blood cell transfusions in acute paediatrics. Arch Dis Child Educ Pract Ed 2009; 94:65-73.

44 Hume HA, Limoges P: Perioperative blood transfusion therapy in pediatric patients. Am J Ther 2002;9:396-405.

45 Executive Committee of the German Medical Association on the recommendation of the Scientific Advisory Board: Cross-sectional guidelines for therapy with blood components and plasma derivatives: Chapter 7 Procoagulators. Transfus Med Hemother 2009;36:419-436.

46 Fries D, Innerhofer P, Perger P, Gutl M, Heil S, Hofmann N, Kneifel W, Neuner L, Pernerstorfer T, Pfanner G, Schochl H, Ziegler B, Kolblinger C, Kozek-Langenecker S: Gerinnungsmanagement bei traumatisch bedingter Massivblutung - Empfehlungen der Arbeitsgruppe für perioperative $\mathrm{Ge}$ rinnung der ÖGARI. Anasthesiol Intensivmed Notfallmed Schmerzther 2010;45:552-561.

47 Stanworth SJ, Brunskill SJ, Hyde CJ, McClelland DB, Murphy MF: Is fresh frozen plasma clinically effective? A systematic review of randomized controlled trials. Br J Haematol 2004;126:139-152.

48 Hildebrandt B, Machotta A, Riess H, Kerner S, Ahlers O, Haberl H, Dorken B, Kerner T: Intraoperative fresh-frozen plasma versus human albumin in craniofacial surgery - a pilot study comparing coagulation profiles in infants younger than 12 months. Thromb Haemost 2007;98:172-177.

49 Stainsby D, MacLennan S, Thomas D, Isaac J, Hamilton PJ: Guidelines on the management of massive blood loss. Br J Haematol 2006;135:634-641.

50 Kerner T, Machotta A, Kerner S, Ahlers O, Haberl H, Riess H, Hildebrandt B: A clinical pilot study of fresh frozen plasma versus human albumin in paediatric craniofacial repair. J Int Med Res 2008;36: 171-177.

51 Stricker PA, Shaw TL, Desouza DG, Hernandez SV, Bartlett SP, Friedman DF, Sesok-Pizzini DA, Jobes DR: Blood loss, replacement, and associated morbidity in infants and children undergoing craniofacial surgery. Paed Anaesth 2010;20:150-159.

52 Stanworth SJ, Grant-Casey J, Lowe D, Laffan M, New H, Murphy MF, Allard S: The use of freshfrozen plasma in England: high levels of inappropriate use in adults and children. Transfusion 2011; 51:62-70.

53 Rahe-Meyer N, Solomon C, Winterhalter M, Piepenbrock S, Tanaka K, Haverich A, Pichlmaier M: Thromboelastometry-guided administration of fibrinogen concentrate for the treatment of excessive intraoperative bleeding in thoracoabdominal aortic aneurysm surgery. J Thorac Cardiovasc Surg 2009;138:694-702. 
-54 Fenger-Eriksen C, Jensen TM, Kristensen BS, Jensen KM, Tonnesen E, Ingerslev J, Sorensen B: Fibrinogen substitution improves whole blood clot firmness after dilution with hydroxyethyl starch in bleeding patients undergoing radical cystectomy: a randomized, placebo-controlled clinical trial. J Thromb Haemost 2009;7:795-802.

55 Fenger-Eriksen C, Lindberg-Larsen M, Christensen AQ, Ingerslev J, Sorensen B Fibrinogen concentrate substitution therapy in patients with massive haemorrhage and low plasma fibrinogen concentrations. Br J Anaesth 2008;101:769-773.

56 Danes AF, Cuenca LG, Bueno SR, Mendarte Barrenechea L, Ronsano JB: Efficacy and tolerability of human fibrinogen concentrate administration to patients with acquired fibrinogen deficiency and active or in high-risk severe bleeding. Vox Sang 2008;94:221-226.

57 Weinkove R, Rangarajan S: Fibrinogen concentrate for acquired hypofibrinogenaemic states. Transfus Med 2008;18:151-157.

58 Dickneite G, Pragst I, Joch C, Bergman GE: Animal model and clinical evidence indicating low thrombogenic potential of fibrinogen concentrate (Haemocomplettan P). Blood Coagul Fibrinolysis 2009;20:535-540.

59 Manco-Johnson MJ, Dimichele D, Castaman G, Fremann S, Knaub S, Kalina U, Peyvandi F, Piseddu G, Mannucci P: Pharmacokinetics and safety of fibrinogen concentrate. J Thromb Haemost 2009;7:2064-2069.

60 Practice Guidelines for Perioperative Blood Transfusion and Adjuvant Therapies: an updated report by the American Society of Anesthesiologists Task Force on Perioperative Blood Transfusion and Adjuvant Therapies. Anesthesiology 2006;105:198-208.

61 Korte W: Fibrinmonomer und Faktor XIII. Neues Konzept bei ungeklärter intraoperativer Blutungsneigung. Hämostaseologie 2006;26(suppl 1):S30-35.

62 Gerlach R, Tolle F, Raabe A, Zimmermann M, Siegemund A, Seifert V: Increased risk for postoperative hemorrhage after intracranial surgery in patients with decreased factor XIII activity: implications of a prospective study. Stroke 2002;33:1618-1623.

63 Korte WC, Szadkowski C, Gahler A, Gabi K, Kownacki E, Eder M, Degiacomi P, Zoller N, Devay J, Lange J, Schnider T: Factor XIII substitution in surgical cancer patients at high risk for intraoperative bleeding. Anesthesiology 2009;110: 239-245.

64 Godje O, Gallmeier U, Schelian M, Grunewald M, Mair H: Coagulation factor XIII reduces postoperative bleeding after coronary surgery with extracorporeal circulation. Thorac Cardiovasc Surg 2006;54:26-33.

65 Wettstein P, Haeberli A, Stutz M, Rohner M, Corbetta C, Gabi K, Schnider T, Korte W: Decreased factor XIII availability for thrombin and early loss of clot firmness in patients with unexplained intraoperative bleeding. Anesth Analg 2004; 99:1564-1569.

66 Uhrig L, Blanot S, Baugnon T, Orliaguet G, Carli PA, Meyer PG: Use of recombinant activated factor VII in intractable bleeding during pediatric neurosurgical procedures. Pediatr Crit Care Med 2007;8:576-579.

67 Heisel M, Nagib M, Madsen L, Alshiekh M, Bendel A: Use of recombinant factor VIIa (rFVIIa) to control intraoperative bleeding in pediatric brain tumor patients. Pediatr Blood Cancer 2004;43:703-705.

68 Ekert H, Brizard C, Eyers R, Cochrane A, Henning R: Elective administration in infants of low-dose recombinant activated factor VII (rFVIIa) in cardiopulmonary bypass surgery for congenital heart disease does not shorten time to chest closure or reduce blood loss and need for transfusions: a randomized, doubleblind, parallel group, placebo-controlled study of rFVIIa and standard haemostatic replacement therapy versus standard haemostatic replacement therapy. Blood Coagul Fibrinolysis 2006;17:389-395.

69 Boffard KD, Riou B, Warren B, Choong PI, Rizoli S, Rossaint R, Axelsen M, Kluger Y: Recombinant factor VIIa as adjunctive therapy for bleeding control in severely injured trauma patients: two parallel randomized, placebo-controlled, double-blind clinical trials. J Trauma 2005;59:8-15; discussion 15-8.

70 Rossaint R, Bouillon B, Cerny V, Coats TJ, Duranteau J, Fernandez-Mondejar E, Hunt BJ, Komadina R, Nardi G, Neugebauer E, Ozier Y, Riddez L, Schultz A, Stahel PF, Vincent JL, Spahn DR: Management of bleeding following major trauma: an updated European guideline. Crit Care 2010;14:R52.

71 Schouten ES, van de Pol AC, Schouten AN, Turner NM, Jansen NJ, Bollen CW: The effect of aprotinin, tranexamic acid, and aminocaproic acid on blood loss and use of blood products in major pediatric surgery: a meta-analysis. Pediatr Crit Care Med 2009;10:182-190.

72 Tzortzopoulou A, Cepeda MS, Schumann R, Carr DB: Antifibrinolytic agents for reducing blood loss in scoliosis surgery in children. Cochrane Database Syst Rev 2008:CD006883.

73 Goobie SM, Meier PM, Pereira LM, McGowan FX, Prescilla RP, Scharp LA, Rogers GF, Proctor MR, Meara JG, Soriano SG, Zurakowski D, Sethna NF: Efficacy of tranexamic acid in pediatric craniosynostosis surgery: a double-blind, placebo-controlled trial. Anesthesiology 2011;114:862-871. 